\title{
Academic Service Quality (ASQ) Before and During Pandemic Covid- 19 by Students and Lecturers
}

\author{
*Alimatus Sahrah, Universitas Mercu Buana Yogyakarta, Indonesia, alimatus.sahrah@mercubuana- \\ yogya.ac.id \\ Ros Patriani Dewi, Universitas Mercu Buana Yogyakarta, Indonesia
}

\begin{abstract}
Currently, the whole world is facing the Covid-19 pandemic where almost all sectors are experiencing its impact; one of them is in university related to the learning system. Distance learning becomes one of the decisions taken as a solution so that the learning process in higher education can still be carried out even in pandemic conditions. The hypothesis proposed is that there are differences in Academic Service Quality (ASQ) before and during the pandemic Covid-19 according to lecturers and students. The subjects of this study are 244 people consisting of 78 lecturers and 166 students at University of Mercu Buana Yogyakarta (UMBY). The data collection method uses the SERVQUAL (service quality) scale, which has five dimensions, namely: tangible, reliability, responsiveness, assurance, and empathy. This scale is distributed in two versions, namely the lecturer and student version, each of which has a reliability coefficient of alpha $(\alpha)$ of 0.959 and 0.860 , and the correlation coefficient between the two is 0.795 . The research data are analyzed using two-way ANOVA statistical technique and it is found that the F-test value is 59.15 ( $p<.01$ ). These results indicate that (1) ASQ before pandemic covid-19 ( mean $=96.14$ ) was significantly higher than during the covid-19 pandemic (mean $=90.01$ ) for students and lecturers; (2) ASQ according to lecturers is significantly higher (mean = 103.62) than ASQ according to students (mean = 88.18); (3) There is an interaction of Time (before Covid) and Subjects (LecturerStudent) on the perception of ASQ which is indicated by an F-test value of $8.27(\mathrm{p}<.05)$.
\end{abstract}

Keywords: lecturers, students, academic service quality, university, pandemic covid-19

Received: 22.11.2020 Accepted: 15.12.2020 $\quad$ Published: 11.01.2021

\section{INTRODUCTION}

Based on the Circular of the Ministry of Health of the Republic of Indonesia concerning the 3rd Revision of the Guidelines for the Prevention and Control of Corona Virus Disease (covid-19), it states that WHO on January 30, 2020 has designated Covid-19 as Public Health Emergency of International Concern (PHEIC) or Kedaruratan Kesehatan Masyarakat Dunia Yang Meresahkan Dunia (KKMMD). In Indonesia, confirmed cases of covid-19 were reported for the first time on March 2, 2020. After a few days, on March 11, 2020, WHO has declared covid-19 a pandemic and Indonesia has reported 27 confirmed cases of covid-19 (Gorbiano, 2020).

The rapid spread of COVID-19 has resulted in fear, anxiety and various worries among citizens of countries around the world (NCIRD, 2020). The massive spread of covid-19 almost throughout the world has an impact on all sectors, including the education sector. According to UNESCO (2020) more than 1 billion and 575 million students are not less than 188 countries around the world are reported to have closed schools and universities as a precautionary measure from countries against spreading COVID-19.

University of Mercu Buana Yogyakarta (UMBY) is one of the universities in Indonesia that implements an online learning process. It is purposed as a response to the circumstances and facts that exist as well as a form of great responsibility to students so that they can continue to get education. University through the Chancellor's Circular states that lecturing activities at the UMBY is implemented by e-learning or online learning. It is a distance learning process carried out using the help of the role of Information and Communication Technology (ICT) (Bilfaqih \& Qomarudin, 2015).

The online learning process or e-learning has to face the reality that the system, infrastructure, and human resources (lecturers and students) are not ready yet. In terms of human resources, lecturers still have difficulty in implementing and tend to use conventional learning methods, while students' learning elearning is carried out in different places and times and the learning process is more intense (Hendrastomo, 2008). Other problems faced in the online learning process are supporting facilities and infrastructure such as Internet access, hardware (devices used), software (online systems), as well as access fees that need to be paid (quota). The condition of the facilities and infrastructure, which are still limited and at the same time minimalist, is a dilemma (Hendrastomo, 2008). 
In the face of this pandemic situation, many countries use technology as one of the most appropriate (if not the only) alternatives to ensure that the education system continues to function (Onyema, Sen \& Alsayed, 2020). Despite the challenges in implementation, several advantages have been acknowledged in the need to shift to remote or online learning, among which stands out the opportunity for rapid progress in the field of digital education, which, in other circumstances, would take years. The shift to the remote learning format has also been assessed as a good opportunity for teachers and students to become stronger, more creative, and innovative (Yokozeki, 2020). Prodjo (2020) quoted the UGM Vice Chancellor for Education, Teaching and Student Affairs, Djagal Wiseso, who predicted that the Covid-19 pandemic will greatly affect learning in higher education. The factors driving the demise of tertiary institutions are the unpreparedness of universities to conduct online learning, the availability of the internet, books and journals that can be accessed online, and the unpreparedness of students themselves to study without being on campus during the Covid-19 pandemic.

The disruption caused by Covid-19 in the educational sector may last longer than expected if a more reliable solution for coronavirus is not found on time, and the spread of the disease continues. UNESCO Director-General, Andrey Azoulayals cited by VOA News (2020), warned that "the global scale and speed of the educational disruption due to coronavirus is unparalleled and, if prolonged, could threaten the right to education". No doubts, unplanned school closures can cause severe problems for students, educators, parents and the society at large. It could negatively affect the academic interest and performance of students. If the students are not engaged productively, it could lead to idleness which might result in youth involvement in crimes, loss of interest in learning, and poor academic performance. The US Centre for Disease Prevention and Control (CDC) also expressed concerns about the implications of school closures. According to the CDC, "longer closures may result in more students congregating outside of schools. Brummet (2014), states that school closing is very controversial, and it can have spillover effects on a large number of students in receiving schools. It can affect the quality of teaching and learning and academic achievement particularly for students with special needs or those with learning difficulties that often requires more physical attention and guidance from the teachers (Meng \& Idris, 2015). Though, technology can be used to remedy some of the fallouts from school closures, but it cannot replace the important effect of face-to-face interactions by students and teachers. Besides, many students do not have the necessary access to supportive technologies which makes it harder to maximize the potentials of learning technology during school closures. However, against all odds, mathematical model and empirical analysis of reactive closures of schools in past pandemics indicates that it reduces the total number of cases in the community by 25 percent and postpones the peak of the pandemic by a week or two, while proactive closures of school during pandemics remains one of the most beneficial interventions that can be employed to mitigate the impact of epidemic disease (Christakis \& Christakis, 2020).

The impact of the covid-19 pandemic for UMBY is quite diverse, such as: in teaching and learning process between lecturers and students can no longer be carried out offline (face-to-face), face-to-face students' activities cannot be held, administrative services can only be done online, stagnation payment of students' tuition fees due to the pandemic impacting the economic sector, most students decide to return to their hometowns and it is uncertain when to return to Yogyakarta because they are still waiting for the certainty of the learning policy at the new normal stage. In addition, the Covid-19 pandemic also has an impact on the possibility of a decline in the number of new students.

Based on the results of a survey conducted online to a number of lecturers and students related to their perceptions of academic service quality (ASQ) Mercu Buana University of Yogyakarta in April 2020, $75 \%$ of lecturers and $40 \%$ of students agreed with online learning as an alternative to academic activities been carried out during the Covid 19 pandemic. According to the lecturers, through online learning, they can still provide lecture material with a more flexible time. For students, they can study as usual and not miss the lecture material, as well as more flexible time. Even though it is not new trend, this online learning is also not fully welcomed by lecturers and students, because $55 \%$ of the lecturers gave disagreement and as many as $82 \%$ of students thought that online learning was more difficult than ordinary learning. Likewise student responses, as many as $50 \%$ of students stated that online learning materials made them feel more pressured because they found it difficult to understand course material and were too burdened with assignments. As many as $25 \%$ of lecturers stated that technical constraints such as internet connection and quota often become obstacles in the online learning process), the level of understanding of the material, the atmosphere of the house and the environment that is not supportive also determines the effectiveness of online learning at home, there is even something that is quite interesting is the presence of friends as a reference for the enthusiasm for learning to be one of the things missed during the implementation of academic activities in the emergency period of Covid-19 spread.

In addition, $60 \%$ of students assessed the performance of lecturers in online learning as not optimal. In the online learning process, according to $38 \%$ of students UMBY lecturers made teaching materials and 
developed them by themselves and as many as $35 \%$ modified teaching materials for online learning. Online lecture activities that take place in real time through various online learning applications, generally use moodle developed by UMBY and other online learning applications such as Whatsapp Group, Google Classroom, Zoom, Google Meet and, so on. Meanwhile, $75 \%$ of the lecturers stated that they had provided academic service quality according to University standards even though they had to use the full e learning system for this one semester.

Based on the survey, the results indicated a gap in academic quality before and during the Covid-19 pandemic. It is according to students and lecturers where learning activities with this online system has been going on for almost a semester at the UMBY. The online learning program on the UMBY has been going on from March 19, 2020 to the present. Before the Covid-19 pandemic, the learning process at UMBY was carried out offline or face-to-face, even though there were 10 percent of courses, namely general subjects that were followed by all study programs, the learning system used an online e-learning system. Before the Pandemic, all academic services were conducted face-to-face. This can be seen in lecture administration services, library services, thesis and thesis guidance, exams, seminars, etc. However, since the pandemic period on March 16, 2020, all forms of academic services have been carried out online.

In order to provide students satisfaction as participants of educational services, it is very important for higher education to organize education/ learning with quality services such as in the fields of academic, administrative, student affairs and, other services. Even though during the Covid-19 pandemic, universities must continue to seek new formulas/ strategy and carry out various innovations so that the learning process can continue well and be accounted for. This is also done by UMBY, which is one of the organizers of higher education under the authority of LLDIKTI Region V Yogyakarta (Nuvriasari \& Harsoyo, 2020)

E-learning or online learning processes are basically in line with constructivism learning theory that knowledge is built by learners through the learning process, not transferred from teacher to learner (Bilfaqih \& Qomarudin, 2015). In addition, online learning has the goal of providing quality online learning services that are massive and open to reach students who are far away (Bilfaqih \& Qomarudin, 2015). Meanwhile, according to Hendrastomo (2008) e-learning process is one of the alternatives to enrich learning models, train students to be more independent, and facilitate access to teaching materials while increasing the ease of access to student interactions with lecturers. So it can be concluded that the learning process using online supports the process of independent learning and easy access to learning materials and interactions that support the increasing academic services to students.

The quality of a university is very much determined by the quality of provided service, where quality service can be identified through customer satisfaction like students. For a university, service satisfaction is more oriented towards students because students are the primary customers of the college. Higher education as a service industry must continue to think about the importance of customer service in a more mature manner, because nowadays it is increasingly realized that customer service and satisfaction are vital aspects in order to survive in business

In service organizations, service is the main product, which is invisible and can only be felt by stakeholders, and its consumption is at the same time as its production. In that sense, every service provided by the producers will immediately feel the results by the stakeholders at that time. Thus, for service organizations, delivering services in accordance with stakeholder expectations is very important as an effort to get stakeholder satisfaction, so that stakeholders are willing to buy back services from the organization (Amin, 2017).

According to Rosita et al (2011) the definition of academic services in the learning curriculum is a systematic effort to facilitate students to master curriculum content through the learning process so that they are able to achieve standard applied competencies. The quality of academic service is a comparison between the academic service perceived by customers or stakeholders (in this case students) with the quality of academic service expected by customers or stakeholders (Pakpahan, 2004).

According to Parasuraman's opinion, service is said to be satisfactory if the service felt is the same or exceeds the expected service quality. This kinds of service are perceived as quality and ideal services. Customer' expectations are reflected in the dimensions of service quality as found by Parasuraman, which states that there are five dimensions of service quality, namely: tangible (physical evidence), reliability (reliability), responsiveness (responsiveness), assurance (assurance) and empathy (in Amin, 2017).

The provision of education should pay attention to the quality of service. Educational activities are not only oriented towards the end result of the educational process, but also through proving good accountability including quality assurance, quality control, and quality improvement. Quality or service quality is an output that is better delivered and standardized through a service (Malik, 2010). The quality of service is also the extent to which the services provided by the company are in accordance with the needs and expectations of customers or how far the difference is between reality and customer expectations for the services they receive (Mulyawan \& Rinawati, 2016). 
The definition of academic quality is the core of the quality of the human education process, tools, curriculum, and facilities that are reflected in the quality of teaching lecturers, the quality of learning materials and the quality of learning outcomes, thus forming a set of abilities (Alma, 2003). According to Sallis, educational institutions need to develop quality systems, in order to be able to prove to the public that these institutions can provide quality and quality services (Triyanto \& Latnip, 2014).

According to Zeithaml \& Bitner (2002), service quality is the level of expected excellence and control over that level of excellence is to meet customer desires. Thus, there are two main factors that affect the quality of service/ services, namely: expected service and perceived service. If the service received or perceived is in line with expected service, then the service quality is perceived as good and satisfying. If the received service exceeds customer expectations, then service quality is perceived as an ideal quality. Conversely, if the received service is lower than the expected one, the quality of the service is perceived as poor. Whether or not the quality of service depends on the service provider in meeting customer expectations consistently.

According to Zeithaml \& Bitner (2002), service quality can be measured from five dimensions, namely: Tangible, Reliability, Responsiveness, Assurance, and Empathy (Empathy). Each dimension has the following indicators:

- For the Tangible dimension, it consists of indicators: Appearance of officers/ apparatus in serving customers, Convenience of place to perform services, Ease of service process, Discipline of officers/ apparatus in providing services, Ease of customer access in service requests and use of tools in service.

- For the Reliability dimension, it consists of indicators: Accuracy of officers in serving customers, clear service standards, the ability of officers to use tools in the service process, and expertise of officers in using tools in the service process.

- For the Responsiveness dimension, it consists of indicators: Responding to every customer/applicant who wants to get service, Officer/apparatus performs service quickly, Officer/apparatus performs services appropriately, Officer/apparatus performs services carefully, Officer/apparatus perform services in a timely manner, and all customer complaints are responded to by officers.

- For the dimension of Assurance, it consists of indicators: Officers provide guarantees on time in services, Officers guarantee costs in services, Officers provide legality guarantees in services, and Officers guarantee certainty of costs in services.

- For the dimension of Empathy, it consists of indicators: Prioritizing the interests of the applicant/customer, Officers serving with a friendly attitude, Officers serving with courtesy, Officers serving non-discriminatory (discriminating), and Officers serving and respecting each customer.

Quality of service must start with customer needs and end with customer's expectations. It means that a good quality image is not based on the producer's point of view, but from the point of view of customer's expectations. Furthermore, Zeithaml and Bitner define customer's expectations as follows "Customer's expectations are the standards of or reference points for performance against which service experiences are compared and are often formulated in terms of what customer believes should or will happen". This means that customer's expectations are a reference standard that becomes a guide for customers before buying a product in assessing the product's performance (Kotler \& Keller, 2012).

Higher education as an educational institution is required to provide quality education services so that it is accountable and has high quality. Higher education as a service industry must begin to think about the importance of customer service in a more mature manner, because now it is increasingly realized that customer service and satisfaction are vital aspects in order to stay in business and win the competition (Tjiptono, 2004).

Academic satisfaction is very important because it will make students loyal to the institution so that they are willing to promote the institution to others, increase public interest in continuing education at the institution, increase the bargaining position of the institution, and improve the image of the institution. For a university, academic satisfaction is more oriented towards students because students are the primary customers of the college. Students relate to input through a selection process then process in the form of intra and extracurricular activities to direct output in all stages of the educational mechanism in higher education, starting from the input mechanism through the selection process to the process in the form of intra and extracurricular activities to output (Sufiyyah, 2011).

Students' satisfaction will provide benefits for universities. Students who are satisfied will use the services of the college with further studies at the same college. In addition, he will also promote good service from the university to other prospective of students so that it will increase the number of students studying at the college. Students' satisfaction in this study is the conformity between the expectations and 
performance of academic and bureaucratic services received by students. Students' satisfaction includes curriculum in accordance with students' expectations, lecture designs that match students' expectations, presentation of material and evaluation in accordance with students' expectations, lecture facilities and infrastructure that are in accordance with students' expectations, laboratories that are in accordance with students' expectations, and appropriate guidance that is in accordance with students' expectations (Sufiyyah, 2011).

In relation to the goals of higher education above, tertiary institutions as providers of higher education have a function known as the Tri Darma of Higher Education, namely education, research, and community service. These functions can only be carried out if the minimum requirements of a university have been met. The requirements referred to are adequate campus infrastructure, laboratory equipment, libraries, and lecturers or a dedicated and professional teaching staff (Tilaar, 1994). In Indonesia, there are several forms of higher education institutions, namely universities, institutes, colleges, and academies, however All forms of higher education institutions can be said to be institutions engaged in the service sector, which have characteristics such as the service industry, namely tangibles, reliability, responsiveness, assurance, and empathy (Freeman \& Dart, 1993). By understanding these quality dimensions, every higher education institution is expected to be able to improve the quality of its teaching and learning process. This is due to the increasingly sharp level of competition among universities, especially between private universities. Wahyuningdyah \& Teguh Budiarto (1996) added that with the increasing number of private universities today, it shows the tighter level of competition between universities.

Students' satisfaction is thought to be determined by the quality of service related to academics. Tampubolon (2001) suggests that academic services have a very large portion of educational services. Academic services are services that are directly related to students, so universities in providing academic services must try to understand and meet students' needs and end up with students' perceptions. The quality of academic services will provide satisfaction to students. Students' satisfaction is aimed at the presence of students' loyalty to higher education and they will tell about satisfying academic services to others. Service quality that includes tangible evidence, empathy (empathy), responsiveness, reliability, and assurance is an effective way of fulfilling people's needs and desires for higher education (Avianti, 2005). .

Educators (tangibles), teaching methods (responsiveness and assurance) and university administration lead to students' satisfaction (Navarro et al., 2005). Higher education management should focus on service quality, information and facilities to improve student satisfaction, and service quality is the most important of all (Helgesen \& Nesset, 2007). Students' satisfaction reflects the perceived difference in offered service quality (Gruber et al., 2010). Communication and responsiveness are the most important determinants of students' satisfaction, but the absence of responsiveness, tangibles, and communication leads to students' dissatisfaction (Douglas et al., 2008).

The covid-19 pandemic has forced everyone to change including universities in implementing distance learning (e-learning) activities. Before the Covid-19 pandemic, online learning methods had been applied in several universities, one of which was conducted by Darmawan (2015) concerning the measurement of the satisfaction level of using e-learning at Pasundan University, Bandung. The results shows the level of satisfaction of students with the use of e-learning is quite low because the value of the level of expectation is higher than the level of reality accepted by students.

The results of other research conducted by Muzid \& Munir (2005) regarding e-learning showed that Universitas Islam Indonesia (UII) students stated that e-learning is currently needed by students to assist their learning process. On average, students admit that they are ready to implement e-learning at UII. This is very useful in the application of e-learning at UII because students are the consumers of the e-learning. If consumers are not ready, the products that are made (e-learning) will be useless, even useless. Based on this research, it can be concluded that sufficient preparation is needed so that distance learning as part of ASQ can meet the expectations of students and lecturers alike so that academic satisfaction is created.

Regarding the Covid-19 pandemic where academic services are online, researchers want to find out whether there are differences in Academic Service Quality (ASQ) before and during the COVID-19 pandemic according to UMBY lecturers and students. The objective of it is that the research results can be an evaluation of higher quality academic services and satisfy UMBY students in this new normal era.

\section{METHOD}

The subjects of this study are 244 consisting of 166 students and 78 lecturers. Students' research subjects have characteristics: aged between 16-25 years, are active students at UMBY, and at least have been UMBY students for 6 months. 
The data collection method in this study used the SERVQUAL scale developed by Parasuraman et al (1996). The SERVQUAL scale has been modified by researchers to reveal the quality of academic services) with five indicators, namely tangible, realiability, responsiveness, assurance, and empathy. The SERVQUAL scale consists of 50 items and is made in two versions, namely the lecturer's version and the student's version. The data are collected via Google Form which is distributed to respondents so that it can be easier and faster in implementation. This scale is structured using a Likert scale with a scale model that provides four alternative answers to choices, namely SS (Very Suitable), S (Suitable), TS (Not Suitable), and STS (Very Unsuitable).

All of those items are feasible to use for research because (1) the value of the item difference coefficient moves between 0.259 and 0.860 for the lecturer's version, and the item of difference coefficient value moves between 0.374 and 0.702 for the student's version, and (2) has an Alpha reliability coefficient $(\alpha)$ which is 0.978 for the lecturer's version, and 0.959 for the student's version of the SERVQUAL scale. It has also been reported that the inter-scale correlation coefficient is $0.795(p<.01)$. It means that both lecturer's and student's versions of the SERVQUAL scale are not different from one another.

The data analysis technique used was the two-way ANOVA statistical test to determine the differences in the quality of academic services before and during Covid for Lecturers and Students.

\section{FINDINGS AND DISCUSSIONS}

This study aims to test whether there are differences in Academic Service Quality (ASQ) before and during the pandemic Covid-19 according to the perceptions of students and lecturers. The research data were analyzed using two-way ANOVA. Before testing the hypothesis, an assumption test was carried out which consisted of a normality test and a linearity test.

Based on the results of the normality test using the Kolmogorov-Smirnov value obtained 0.038 (p> .05), which means that the data distribution is normal, while the homogeneity value seen from the Levene test obtained an F value of $2.677(\mathrm{p}=0.05)$, so it can be declared almost homogeneous.

Table 1: Two-way ANOVA summary: Subject (Lecturer-Student) \& Time (Before Covid-Covid)

\begin{tabular}{|c|c|c|c|c|c|}
\hline Source & $\begin{array}{r}\text { Type III Sum of } \\
\text { Squares }\end{array}$ & df & Mean Square & $\mathbf{F}$ & Sig. \\
\hline Corrected Model & $31101.660^{\mathrm{a}}$ & 3 & 10367.220 & 59.151 & .000 \\
\hline Intercept & 3870365.198 & 1 & 3870365.198 & 22082.725 & .000 \\
\hline Time & 2400.114 & 1 & 2400.114 & 13.694 & .000 \\
\hline Subject & 25078.235 & 1 & 25078.235 & 143.086 & .000 \\
\hline Time * Subject & 1449.184 & 1 & 1449.184 & 8.268 & .004 \\
\hline Error & 84478.524 & 482 & 175.267 & & \\
\hline Total & 4325879.000 & 486 & & & \\
\hline Corrected Total & 115580.183 & 485 & & & \\
\hline \multicolumn{6}{|c|}{$\begin{array}{l}\text { Dependent Variable: Service Quality; Subject: Lecture \& Student; Time: Before Covid \& } \\
\text { Covid }\end{array}$} \\
\hline \multicolumn{6}{|c|}{ a. $\mathrm{R}$ Squared $=.269$ (Adjusted R Squared $=.265$ ) } \\
\hline
\end{tabular}

After the prerequisite test was met, a TWO WAY ANOVA analysis was performed, and the results can be reported in table 1: Two-way ANOVA summary (Subject and Time).

Based on table 1 it can be seen that the F-test Corrected Model shows a value of $59.151(\mathrm{p}<0.01)$. This means that this analysis model is valid, where there is influence of the subject variables (lecturers and students) with an F-test value of 143.086 ( $\mathrm{p}<.01$ ), the time variable (before covid and covid) with an F-test value of $13,694(p<.01)$, as well as the significant interaction effect of the two variables.

These results are in line with the article that discusses the impact of the online learning system in universities in the Covid-19 pandemic era written by Agus \& Samuri (2018). In this article, it is explained that online learning still has many obstacles such as signal interference, inadequate Internet quota, and so on. Distance learning is also less effective than face-to-face learning. It is because students studying exact sciences will find it difficult to understand exact science concepts properly so that it becomes a challenge for students studying this science, especially in the fields of biology, chemistry, physics, and mathematics. Not only difficulties in understanding the concept, but also students who should do practicum become obstructed. However, some universities have implemented online practicum through an available application or website. There are also those who apply it by analyzing videos on the Internet. This of course is still not optimal, because you cannot practice it directly. 
The results of research from Anhusadar (2020) entitled "PIAUD Students' Perceptions of Online Lectures during the Covid 19 Pandemic". It shows that students prefer face-to-face lectures compared to online lectures. It is because the interaction between lecturers and students can be done in a classroom and does not require an application.

In more detail, when viewed from the description of the research data, it shows that there are differences in perceptions between lecturers and students regarding ASQ before and during the Covid-19 pandemic, as shown in table 2.

Table 2: Description of Academic Service Quality (ASQ) Lecturer-Student data before and during pandemic covid-19

\begin{tabular}{|l|l|r|r|r|}
\hline Time & Subject & Mean & Std. Deviation & $\mathbf{N}$ \\
\hline Before Covid & Lectures & 104.16 & 11.530 & 77 \\
\hline & Students & 92.43 & 12.934 & 166 \\
\hline & Total & 96.14 & 13.628 & 243 \\
\hline Covid & Lectures & 103.09 & 11.955 & 77 \\
\hline & Students & 83.94 & 14.752 & 166 \\
\hline & Total & 90.01 & 16.522 & 243 \\
\hline Total & Lectures & 103.62 & 11.718 & 154 \\
\hline & Students & 88.18 & 14.489 & 332 \\
\hline & Total & 93.08 & 15.437 & 486 \\
\hline
\end{tabular}

The data descrbed in Table 2 can also be concluded that (1) ASQ before pandemic covid-19 (mean = 96.14) is significantly higher than ASQ pandemic covid-19 (mean = 90.01) for students and lecturers; (2) ASQ according to lecturers is significantly higher (mean =103.62) than ASQ according to students (mean = 88.18); (3) There is an interaction of Time (before Covid-Covid) and Subjects (Lecturer-Student) on the perception of ASQ which is indicated by an F-test value of $8.27(\mathrm{p}<.05)$. The conclusion of this difference description can be visualized in Figure 1.

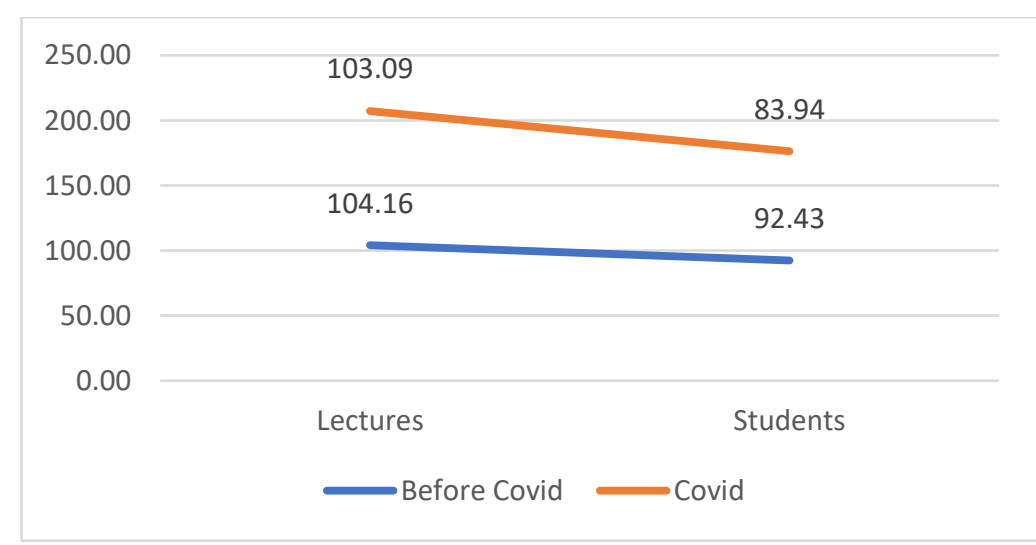

Figure 1. Difference in Mean ASQ for Lecturers and Students on Before and During the Covid-19 Pandemic

The results indicate that there are differences in perceptions between lecturers and students towards ASQ. Even if lecturers and students agree that there is a decrease in ASQ before and during the Covid-19 pandemic, there are differences in ASQ levels between lecturers and students before and during the COVID-19 pandemic. According to the lecturers' perceptions, they have performed higher academic services than those received by students. It means that students perceive academic services provided by lecturers to be lower during the online learning period (Covid-19 pandemic). The results of this study are in line with the research of Hassel \& Ridout (2018) which shows that there are some similarities between student and lecturer expectations, but there is also a lot of evidence of discrepancies. These results were also obtained in Koesworo's (2000) study regarding differences in expectations of the quality of academic services at Unika Widya Mandala Surabaya based on the dimensions of lecturer respect and dimensions of lecturer knowledge. In this study, it can be concluded that there is a gap between student expectations in this case on the dimension of lecturers' respect for students, implying that what the lecturers felt or did so far are not what students expected. 
Based on study in Pakistan, despite gaining immense popularity today, digital technology has still not been embraced by the Medical and Dental students for use in teaching. Students are still more inclined towards face to face teaching rather than e-teaching. Administration and faculty members should take necessary measures for improving e-teaching quality to help with better learning of students during lock down. The research shows that out of 382 students, $76 \%$ of them used mobile gadgets for their e-learning. $77.4 \%$ students showed negative perception about e-learning, out of which $86 \%$ students felt e-learning has little impact on their learning. Majority of the students preferred face to face teaching over e-teaching. The key outcome of the result shows that the students are not yet ready for e-learning (Abbasi et al., 2020). This research indicates that there is a gap between expectations and the reality received by students as consumers of academic services quality during the pandemic Covid-19, which requires the learning process to be done online.

The differences in every aspect of ASQ before the Covid-19 pandemic and during the Covid-19 pandemic, the lecturers and students can be described as in table 3.

Table 3: Mean of Each Aspect of ASQ Lecturer-Student Before and During the Covid-19 Pandemic

\begin{tabular}{|l|l|l|l|l|}
\hline Subject & Aspect ASQ & Before Covid & During Covid & t-test \\
\hline Lectures & & & & \\
\hline & Tangibles & 19.57 & 19.81 & -1.610 \\
\hline & Reliability & 21.06 & 20.69 & $2.61^{* *}$ \\
\hline & Responsiveness & 21.27 & 20.84 & $3.44^{* *}$ \\
\hline & Assurance & 21.06 & 20.48 & $4.25^{* *}$ \\
\hline & Empathy & 21.18 & 21.27 & -0.670 \\
\hline & Total & 104.16 & 103.09 & $2.09^{*}$ \\
\hline & & & & \\
\hline & Tangibles & 18.60 & 17.51 & $6.44^{* *}$ \\
\hline & Reliability & 18.93 & 16.98 & $10.71^{* *}$ \\
\hline & Responsiveness & 18.41 & 16.85 & $8.03^{* *}$ \\
\hline & Assurance & 18.14 & 15.89 & $9.81^{* *}$ \\
\hline & Empathy & 18.34 & 16.72 & $7.23^{* *}$ \\
\hline & Total & 92.43 & 83.94 & $9.95^{* *}$ \\
\hline
\end{tabular}

From table 3, it can be concluded that ASQ according to the lecturers, as a whole acknowledges that there is a decrease in ASQ during the pandemic covid-19 compared to before the Covid-19 pandemic, but the lecturers consider that in terms of tangible and empathic aspects, there is difference. Meanwhile, according to the students, ASQ during pandemic covid-19 as a whole as well as in every aspect of ASQ (Tangible, Reliability, Responsiveness, Assurance and Empathy) is lower than ASQ before pandemic covid19.

The Tangibles aspect in this study refers to physical evidence from ASQ, namely: informative and interesting faculty websites, e-learning websites that are used as online learning media that are easily accessible and used, use of academic information systems (SIA), teaching materials to complement lecture materials, and online library facilities (Osuyi \& Eboh, 2020). Based on research data, the results show that there is a significant difference in ASQ before the Covid-19 pandemic and during the Covid-19 pandemic according to students and lecturers. According to students, in this aspect of tangibles, supplementary teaching materials (handouts, modules, videos, etc.) given to them to complement the lecture material are less easy to understand. Lecturers also have the same perception as students that teaching materials before the Covid-19 pandemic are more effectively used to deliver lecture material. These results indicate that teaching materials are easier to learn during face-to-face lectures (offline). Before the Covid-19 pandemic, physical supplement teaching materials were easier for students to understand. Lecturers can explain learning materials more clearly face to face with LCD media and whiteboards. Students feel that they can better capture what lecturers say face-to-face rather than through online learning application media, such as: moodle e-learning, zoom cloud meeting, google meet, youtube, and various other online learning platforms. The offline library facilities before the Covid-19 pandemic also made it considered easier for students to find references, such as books, journals, theses, theses, and various other references (Purwandani, Sutarsih \& Sururi, 2016).

In the aspect of reliability, namely the reliability of the teaching staff and teaching staff in serving students, there is a significant difference in the first item from the aspect of reliability, namely "lecturers deliver material in an interesting and fun way". There is a significant difference in this item where students feel that before the Covid-19 pandemic, lecturers delivered the material in a more interesting and fun way. 
The same finding also applies to lecturers, where lecturers stated that it was easier for them to convey material to students before the covid-19 pandemic compared to during the covid-19 pandemic where all teaching are online. Before the covid-19 pandemic, the learning process was carried out face-to-face, lecturers could directly interact with students during the lecture process, so that students could more easily understand the material provided because the material was real, not virtual. The discussion process can also be more dynamic when the lecture process is face-to-face and does not have to be constrained by internet connections or signals that can interfere with the learning process.

In the Responsiveness aspect, which is a fast responsive service from teaching staff and educators, a striking difference is found in the first item, namely: "the lecturer answers student questions clearly and is easy to understand". Students feel that online learning activities make teachers not to answer student questions clearly and make students less understand the material. Likewise with lecturers who also stated that it was easier for them to answer questions when lectures were conducted face-to-face. Before the Covid-19 pandemic, various questions asked by students to lecturers regarding lecture material or just consulting about a problem could be responded to directly by lecturers and teaching staff because they were face-to-face. Unlike during the Covid-19 pandemic, all kinds of complaints and questions must be responded to online and it often makes students dissatisfied because sometimes information is misinterpreted (miscommunication occurs).

In the aspect of Assurance, which is the guarantee provided by teaching staff and educators in providing services to students, a significant difference was found in the second item, namely: "complaints from students are handled immediately by the lecturer without waiting for a long time". Students have the perception that lecturers are not fast enough in handling complaints from students related to lectures, whereas according to lecturers, they are fast enough to serve student complaints by taking the time as soon as possible to respond to questions or complaints from students. In this aspect, the data related to the lecturers' perceptions of the assurance aspect, the prominent results are the first item, namely: "the lecturer imposes academic sanctions on all students who violate the rules fairly". According to the lecturer, academic sanctions are easier to apply before the covid-19 pandemic.Before the Covid-19 pandemic, students could interact face-to-face with lecturers or teaching staff to submit complaints and immediately get responses or answers. At the time of the Covid-19 pandemic, all forms of questions or complaints from students had to go through the online system, be it via the WhatsApp application, SMS (Short Message Service), or telephone and did not necessarily get an immediate response. Sometimes some lecturers and teaching staff are slow to respond, and do not immediately guarantee accurate information to students. This is what often causes miscommunication. Lecturers also find it easier to apply academic rewards and sanctions when the lecture process is carried out offline.

In the aspect of Empathy, namely the attitude of empathy shown by teaching staff and educators, a significant difference in student data is in the first item, namely "lecturers often ask about the obstacles faced by students in studying course material". Students feel that during online learning (during the Covid19 pandemic), lecturers show less empathy because they rarely ask about obstacles or difficulties for students in understanding course material, while lecturers assume that they are empathetic enough to the obstacles faced by students related to understanding course material. In this aspect, lecturers think that they are not able to monitor student progress towards understanding the material conveyed through online learning. Regarding online learning, it is not easy to show empathy to students as recipients of academic services, because the interaction process occurs virtually. Most students find it difficult to understand online course material, but the lecturers are less sensitive to the difficulties faced by students. Students feel that lecturers rarely ask about obstacles that students encounter while participating in distance learning.

The created academic satisfaction can increase students' loyalty as consumers of an educational institution. Various studies on ASQ (Manik \& Sidharta, 2017; Muzakki \& Tarigan, 2020; Rahareng \& Volunteer, 2017; Yusuf, 2018) have concluded that ASQ has a very strong influence on student satisfaction. If the received or perceived service is as good as expected service, then the service quality is perceived as good and satisfying. If the received service exceeds customer expectations, then service quality is perceived as ideal quality. Conversely, if the received service is lower than expected, the quality of the service is perceived as poor. Whether or not the quality of service depends on service providers (universities) in meeting the expectations of their customers (students) consistently (Zeithaml \& Bitner, 2002). Therefore, the positive perceptions of students towards ASQ given by higher education are expected to increase student academic satisfaction so that it can also have a positive effect on organizational performance.

The service delivery process that occurs in higher education institutions cannot be separated from the existence of students as customers of the education services offered. Higher education as a service provider must be able to meet the expectations of its students, and minimize any gaps according to their abilities. Students as customers of higher education institutions also have the same behavior when they 
make a purchase of an item with a service purchase. The buying behavior of both goods and services is seen in the process of acquisition, consumption, experience, and ideas (Minor, 2002).

Based on the results of research from Bakrie (2019), service quality greatly affects the reputation of the institution and student satisfaction. Therefore, educational institutions need to continue to strive for and improve service quality in order to increase student satisfaction and the reputation of educational institutions, which in turn can increase student loyalty to higher education institutions. The influence of institutional reputation on loyalty is the most significant factor, where the higher the reputation of the institution will be able to increase student loyalty to higher education institutions.

Student loyalty is one of the keys to success in managing higher education. Students will not do demonstrations, and move to another place. Students will be willing to recommend others to study where they are currently studying, and are willing to continue their Masters studies and maintain good relations with universities. The four things above are the strategic impact of student loyalty to higher education. The findings of this study have implications for managerial parties in order to increase student loyalty. The results of the study show that service quality is the right instrument to measure service quality in education. In addition, because all dimensions of service quality attributes are positively correlated with customer satisfaction and reputation, educational institutions must emphasize all dimensions of service quality in maintaining and improving service quality for students. In an effort to build student loyalty, things that need to be a concern for higher education management are continuing, maintaining and enhancing the reputation of the institution as well as continuing and improving service quality in order to provide student satisfaction and form better student loyalty (Bakrie, 2019).

\section{CONCLUSION AND SUGGESTION}

Based on the results of research and discussion, it can be concluded that there are significant differences in Academic Service Quality (ASQ) before and during the pandemic Covid-19 according to lecturers and students. According to the lecturers, overall admitted that there has been a decrease in ASQ during the pandemic covid-19 compared to before the covid-19 pandemic, but the lecturers consider that in terms of tangible and empathic aspects, it is not different. According to the students, ASQ during the pandemic covid19 as a whole and in every aspect (Tangible, Reliability, Responsiveness, Assurance and Empathy) has decreased compared to before the Covid-19 pandemic.

Thus, it becomes a challenge for higher education institutions so that during the pandemic and for the next learning process to improve ASQ in terms of Tangible, Reliability, Responsiveness, Assurance and Empathy because it becomes the core business of educational institutions. The lecturers are expected to further improve the learning patterns that are more tangible and show more empathy to students during the Covid-19 pandemic, because although according to the lecturers this is not different, according to the students it is perceived as showing a decrease.

Efforts to increase ASQ for students as consumers are the main thing for educational institutions. Therefore, it is recommended for universities to be able to increase ASQ by evaluating academic services during the Covid-19 pandemic, and trying to improve aspects that are still high in gaps, in this case the aspects of Tangible, Reliability, Responsiveness, Assurance and Empathy. Higher education must be able to answer the challenges faced by the world of education today by providing optimal service quality, one of which is by providing training for teaching staff to be more creative and interactive in conducting online learning. Lecturers must be able to stimulate student independence and creativity by creating an interesting, dynamic, and fun learning process even though it must be done online. Likewise with the teaching staff, it is better if training on excellent service online is also provided in order to satisfy students.

For further research, it is advisable to conduct research on Subjective Well-Being (SWB) as well as positive feelings and negative feelings experienced by lecturers and students before and during the COVID19 pandemic, as one way to see indicators of efforts to increase ASQ to obtain student satisfaction in following the learning process. Based on study in Kosovo, the new circumstances created due to the spread of COVID-19, including changes in education, have caused a number of concerns among students, parents, and teachers in Kosovo. The findings from the study confirm the common concerns of the two reporting groups in the study in relation to student assessment, worries and overload, as well as evaluations of the incompatibility of the learning conducted so far. The findings of this study confirm the readiness and motivation of teachers to advance their knowledge and skills, as well as to contribute with the aim of advancing the quality of education. Opportunities to advance the quality of online learning, the support of teachers, parents, and families, coupled with practical suggestions for parties involved in the field of education, are also included (Duraku \& Hoxha, 2020). 


\section{REFERENCES}

Abbasi, S., Ayoob, T., Malik, A., \& Memon, S. I. (2020). Perceptions of students regarding e-learning during covid-19 at a private medical college. Pakistan Journal of Medical Sciences, 36(COVID19-S4), S57S61. https://doi.org/10.12669/pjms.36.COVID19-S4.2766.

Agus, R., \& Samuri, S. M. (2018). Learning Analytics Contribution in Education and Child Development: A Review on Learning Analytics. Asian Journal of Assessment in Teaching and Learning, 8, 36-47. https://doi.org/10.37134/ajatel.vol8.4.2018.

Alma, B. (2003). Pemasaran Stratejik Jasa Pendidikan. Bandung: Alfabeta.

Amin, S. (2017). Strategi Peningkatan Kualitas Pelayanan Akademik Pada Perguruan Tinggi. Madaniyah, $7(2), 223-235$.

Anhusadar, L. O. (2020). Persepsi Mahasiswa PIAUD terhadap Kuliah Online di Masa Pandemi. KINDERGARTEN: Journal of Islamic Early Childhood Education, 3(1), 44-58. https://doi.org/10.24014/kjiece.v3i1.9609

Avianti. (2005). Manajemen Kualitas Pendekatan Sisi Kualitatif. Penerbit Remaja Rosdakarya.

Bakrie, F. R. (2019). Pengaruh Konservatisme Akuntansi, Sales Growth, Ukuran Perusahaan Dan Capital Intensity Terhadap Penghindaran Pajak Perusahaan (Studi Empiris Pada Perusahaan Manufaktur Sub Sektor Makanan dan Minuman Yang Listing di Bursa Efek Indonesia pd thn 2013-2017) (Doctoral dissertation, Universitas Mercu Buana Jakarta).

Bilfaqih, Y., \& Qomarudin, M. . (2015). Esensi Pengembangan Pembelajaran Daring. Panduan Berstandar Pengembangan Pembelajaran Daring untuk Pendidikan dan Pelatihan. Deepublish. https://doi.org/10.1109/ICASI.2017.7988469

Brummet, Q. (2014). The effect of school closings on student achievement. Journa Lf Public Economics, 119, 108-124. https://doi.org/https://doi.org/10.1016/j.jpubeco.2014.06.010

Christakis, E., \& Christakis, N. A. (2020). Closing the Schools Is Not the Only Option Districts can give parents some flexibility while implementing stronger mitigation measures. Retrieved 19 May, 2020 from https://www.theatlantic.com/ideas/archive/2020/03/coronavirus-closing-schools-not-onlyoption/608056/

Darmawan, F. (2015). Pengukuran Tingkat Kepuasan Pemanfaatan E-Learning. Jurnal Speed-Sentra Penelitian Engineering Dan Edukasi, 7(4), 63-71.

Douglas, J., McClelland, R., \& Davies, J. (2008). The Development of a Conceptual Model of Student Satisfaction with Their Experience in Higher Education. Quality Assurance Education, 16(1), 19-35.

Duraku, Z. H., \& Hoxha, L. (2020). The impact of COVID-19 on education and on the well-being of teachers, parents, and students: Challenges related to remote (online) learning and opportunities for advancing the qua ... The impact of COVID-19 on education and on the well-being of teac. ResearchGate, April. https://www.researchgate.net/publication/341297812\%0AThe

Freeman, K. D. dan Dart, J. (1993). Measuring The Perceived Quality of Business Services. Journal of Proffesional Services Marketing, 9(1), 27-41.

Gorbiano, M. I. (2020). BREAKING: Jokowi announces Indonesia's first two confirmed COVID-19 cases The Jakarta Post, March 2. https://www.thejakartapost.com/news/2020/03/02/breaking-jokowiannounces-indonesias-first-two-confirmed-covid-19-cases.html.

Gruber, T., Fub, S., Voss, R., \& Zikuda, M. G. (2010). Examining Student Satisfaction with Higher Education Services Using A New Measurement Tool. International Journal of Public Sector Management, 23(2), 105-123.

Hassel, S., \& Ridout, N. (2018). An Investigation of First-Year Students' and Lecturers' Expectations of University Education. Frontiers in psychology, 8, 2218. https://doi.org/10.3389/fpsyg.2017.02218

Helgesen, O., \& Nesset, E. (2007). What Accounts for Students' Loyalty? Some Field Study Evidence. International Journal of Educational Management, 21(2), 126-143.

Hendrastomo, G. (2008). Dilema dan tantangan pembelajaran e-learning. Majalah Ilmu Pembelajaran.

Kotler, P., \& Keller. (2012). Manajemen Pemasaran, Edisi ke 12. Jakarta: Erlangga.

Malik, A. (2010). Model pembelajaran inkuiri dengan menggunakan virtual laboratory dan real laboratory untuk meningkatkan penguasaan konsep dan keterampilan berpikir kritis siswa SMA 1 pada topik listrik dinamis. UPI Bandung.

Manik, E., \& Sidharta, I. (2017). Munich Personal RePEc Archive The Impact of E-banking on Customer Satisfaction in Nigeria. Munich Personal RePEc Archive.

Meng, C. C., \& Idris, N. (2015). Form Four Science Students' Perceptions of the Quality of Learning Experiences Provided by Assessments in STEM Related Subjects. Asian Journal of Assessment in Teaching and Learning, 5, 50-56.

Minor, J. (2002). Incorporating Service Learning into ESOL Programs. Tesol Journal, 11(4), 10-14. 
Mulyawan, A., \& Rinawati. (2016). Pengaruh kualitas layanan akademik terhadap kepuasan mahasiswa serta implikasinya pada loyalitas mahasiswa (studi pada sekolah tinggi manajemen informatika dan komputer di kota Bandung). Jurnal Ekonomi, Bisnis \& Entrepreneurship, 10(2).

Muzakki, M. A., \& Tarigan, Z. J. H. (2020). The Analysis of the Effect of Academic Service Quality on Student Loyalty Through Student Satisfaction and Organizational Performance. Petra International Journal of Business Studies, 3(1), 47-53. https://doi.org/10.9744/ijbs.3.1.47-53

Muzid, S., \& Munir, M. (2005). Persepsi Mahasiswa Dalam Penerapan e-Learning sebagai Aplikasi Peningkatan Kualitas Pendidikan (Studi Kasus Pada Universitas Islam Indonesia). Seminar Nasional Aplikasi Teknologi Informasi 2005 (SNATI 2005), 2005(Snati), 8.

Navarro, M. M., Iglesias, M. P., \& Torres, P. R. (2005). Measuring Customer Satisfaction in Summer Courses. Quality Assurance Education, 13(1), 53-65.

NCIRD, (2020). Coronavirus Disease 2019. National Center for Immunization and Respiratory Diseases (NCIRD). Division of Viral Diseases. Marrenga: https://www.cdc.gov/coronavirus/2019ncov/daily-life-coping/managing-stress-anxiety.html

Nuvriasari, A., \& Harsoyo, T. D. (2020). Evaluasi pelaksanaan pembelajaran online di tengah pandemi covid19. Covid-19 dalam ragam tinjauan perspektif. McBridge Press Yogyakarta.

Onyema, E. M., Sen, S., \& Alsayed, A. O. (2020). Impact of Coronavirus Pandemic on Education. Journal of Education and Practice, May. https://doi.org/10.7176/jep/11-13-12.

Osuyi, S. O., \& Eboh, P. A. (2020). Analysis of the relevance of basic electricity to Home Economics Students in Technical Colleges in Edo State, Nigeria. Asian Journal of Assessment in Teaching and Learning, 10(2), 27-33. https://doi.org/10.37134/ajatel.vol10.2.4.2020.

Pakpahan, S. P. (2004). Persepsi Mahasiswa UPBJJ-UT Medan Tentang Pelayanan Akademik dan NonAkademik yang Diberikan Oleh UPBJJ-UT Medan. Jurnal Pendidikan Terbuka Dan Jarak Jauh, 5(1), 47-58.

Parasuraman, A., Zeithaml, V., \& Berry, L. (1996). SERVQUAL : Multiple Item Scale for Measuring Consumer Perceptions of Service Quality. Journal of Retailing, 64, 12-40.

Purwandani, D., Sutarsih, C., \& Sururi. (2016). Pengaruh Mutu Layanan Sarana dan Prasarana Terhadap Kepuasan Mahasiswa di Fakultas Pendidikan Teknologi dan Kejuruan Universitas Pendidikan Indonesia. Jurnal ADPEND, https://ejournal.upi.edu/index.php/jurnaladpend/article/view/3755/2674.

Prodjo, W. A. (2020). Apa itu Belajar dari Rumah. Melihat Kembali Konsep Awal... Retrieved from kompas. com website: https://edukasi. kompas. com/read/2020/04/14/163041771/apa-itu-belajar-darirumah-melihat-kembali-konsep-awal.

Rahareng, V. J., \& Relawan, N. (2017). The Influence of the Academic Service Quality Toward Student Satisfaction (Study on Students of Business Administration of Telkom University). Jurnal AdBispreneur, 2(2), 125-133.

Rosita, T., D., S., Susanti, \& Nurhasanah. (2011). Pedoman penyelenggaraan program pascasarjana. Edisi Kedua, Cetakan Ketiga. Penerbit Universitas Terbuka.

Sufiyyah, A. (2011). Pengaruh Kualitas Layanan Akademik dan Birokrasi terhadap Kepuasan Mahasiswa. Jurnal ISSN, 13(2), 85-93.

Tampubolon, D. P. (2001). Perguruan tinggi bermutu. Jakarta: Gramedia Pustaka Utama.

Tilaar, M. (1994). Managemen Pendidikan nasional, Kajian Pendidikan Masa Depan. Yogyakarta: PT Remaja Rosdakarya.

Tjiptono, F. (2004). Manajemen Jasa. Yogyakarta: Andi Offset.

Triyanto, \& Latnip, D. P. (2014). Implementasi Penyelenggaraan ISO 9001:2008 dalam Bidang Mutu Layanan Administrasi Akademik. Jurnal Akuntabilitas Manajemen Pendidikan, 1(1), 150-161.

VOA News. (2020). UNESCO: 290 Million Students Stay Home due to Coronavirus. retrieved 10 May, 2020 from https://learningenglish.voanews.com/a/unesco-290-million-students-stay-home-due-tocoronavirus/5317148.html

UNESCO. (2020). Covid-19 Impact on Education Data. COVID-19 Education Disruption and Response. The United Nations Educational, Scientific and Cultural Organization, UNESCO.

Koesworo, Y. (2009). Analisis Perbedaan Harapan Kualitas Layanan Akademis Di Unika Widya Mandala Surabaya. 395, 183-200. https://doi.org/10.24034/j25485024.y2001.v5.i2.1928.

Wahyuningdyah, R. Y., \& Teguh Budiarto, M. I. M. (1996). Analisis posisi Fakultas Ekonomi jurusan Manajemen beberapa Perguruan Tinggi Swasta di Kopertis Wilayah V (Doctoral dissertation, [Yogyakarta]: Universitas Gadjah Mada).

Yokozeki. (2020). COVID-19 Webinar: A new world for teachers, education's frontline workers. Marrë nga retrieved 21 July, 2020 from https://en.unesco.org/news/covid-19-webinar-newworld- teacherseducations-frontline-workers. 
Yusuf, M. (2018). The Influence of Quality Academic Service on Student Satisfaction (Empiric Study on Bidikmisi Scholarship Students Regional Office of Universitas Terbuka At Pangkalpinang, Indonesia). IJBE (Integrated Journal of Business and Economics), 2(2), 40. https://doi.org/10.33019/ijbe.v2i2.75 Zeithaml, V. A., \& Bitner, M. J. (2002). Service Marketing. New York: McGraw Hill Inc, Int'l Edition. 